\title{
HAKIKAT PERJANJIAN REKLAMASI PANTAI ANTARA INVESTOR DENGAN PEMERINTAH PROVINSI SULAWESI SELATAN
}

\author{
Asbudi Dwi Saputra \\ Mahasiswa Program Doktor Ilmu Hukum Pascasarajana UMI Makassar \\ email : anzar2017@ymail.com
}

\begin{abstract}
Itself the reclamation agreement between the Government of South Sulawesi province with investors have not materialized as it should be, because in the reclamation agreement has ignored the principles in contract law and the terms of a legal contract. There are discrepancies in the legislation between Article 8 of the Regulation of the Minister of Marine and Fisheries of the Republic of Indonesia Number 28 / Candy-Kp/2014 concerning the licensing of reclamation in coastal regions and small islands with Presidential Decree No. 122 of 2012 on reclamation in coastal regions and small islands and Act No. 23 of 2014 on local government authority to permit the location of the reclamation.
\end{abstract}

Keywords : Agreement; Coastal Reclamation; Investor; Government;

\begin{abstract}
Abstrak
Perjanjian reklamasi itu sendiri antara Pemerintah Provinsi Sulawesi Selatan dengan investor belum terwujud sebagaimana mestinya, karena dalam perjanjian reklamasi telah mengabaikan prinsip-prinsip dalam hukum kontrak dan ketentuan-ketentuan kontrak hukum. Ada perbedaan dalam undang-undang antara Pasal 8 Peraturan Menteri Kelautan dan Perikanan Republik Indonesia Nomor 28 / Candy-Kp / 2014 tentang perizinan reklamasi di wilayah pesisir dan pulau-pulau kecil dengan Keputusan Presiden No. 122 dari 2012 tentang reklamasi di wilayah pesisir dan pulau-pulau kecil dan Undang-Undang No. 23 tahun 2014 tentang otoritas pemerintah daerah untuk mengizinkan lokasi reklamasi.
\end{abstract}

Kata kunci: Perjanjian; Reklamasi Pantai; Pemodal; Pemerintah

\section{A. PENDAHULUAN}

Reklamasi pantai sebagai alternatif pemenuhan kebutuhan lahan perkotaan menjadi kemutlakan, karena semakin sempitnya wilayah daratan di Kota Makassar. Kebutuhan dan manfaat reklamasi dapat dilihat dari aspek tata guna lahan, aspek pengelolaan pantai dan ekonomi. Tata ruang suatu wilayah tertentu kadang dibutuhkan untuk direklamasi agar dapat berdaya dan hasil guna. Untuk pantai yang diorientasikan bagi pelabuhan, industri, wisata atau untuk kepentingan umum yang perairan pantainya dangkal wajib untuk direklamasi agar bisa dimanfaatkan.

Vol. 20 No. 1 Mei 2018 
Upaya perwujudan reklamasi kawasan pantai di Kota Makassar dilaksanakan melalui kerjasama (partnership) dengan pihak swasta, yang pelaksanaannya telah menghasilkan berbagai dokumen kerja sama, seperti Nota Kesepahaman $(\mathrm{MoU})$ yang bernomor 252/VII/PEMPROV/2013 dan 231/YBA/VII/2013, tertanggal 29 Juli 2013 Tentang Perjanjian Kerjasama antara Pemerintah Provinsi Sulawesi Selatan dengan PT. YASMIN BUMI ASRI mengenai Reklamasi Kawasan Centre Point Of Indonesia di Kota Makassar. Kemudian PT. Ciputra Development Tbk melalui Kerja Sama Operasi (KSO) Ciputra Yasmin telah menunjuk kontraktor PT Boskalis Internasional Indonesia sebagai pemenang tender proyek Centre Point of Indonesia (CPI) di Makassar, kontrak berlangsung selama dua tahun. Namun dalam perkembangannya pelaksanaan reklamasi tersebut, menuai banyak kritikan dan pertentangan mulai dari payung hukum reklamasi sampai pada hak atas tanah yang telah direklamasi.

Dalam perjanjian kerjasama yang tertuang dalam MoU Nomor : 252/VII/Pemprov/2013, pada Pasal 4 ditentukan bahwa Pihak Kesatu (Pemprov) hanya berhak memperoleh hasil pekerjaan berupa lahan tereklamasi seluas $\pm 50,47 \mathrm{Ha}$, sedangkan pihak Kedua (Investor) diberikan lahan seluas $\pm 106,76$ Ha dari total lahan yang direklamasi seluas 157,23 Ha. Kemudian dalam pasal 5, bahwa pemerintah provinsi harus memenuhi sejumlah kewajiban yang mengakibatkan biaya yang dikeluarkan mencapai 164,1 Milyar. Sementara kewajiban investor hanya menyiapkan desain, mengurus perizinan dan menyiapkan material untuk reklamasi.

Ketentuan tersebut, memberi indikasi bahwa apa yang akan diperoleh pemerintah daerah berupa lahan yang telah tereklamasi sangat kecil, dibandingkan apa yang diperoleh investor. Pemerintah hanya mendapatkan lahan tereklamasi seluas $\pm 50,47 \mathrm{Ha}$, sedangkan pihak kedua (investor) diberikan lahan seluas $\pm 106,76$ Ha dari total lahan yang direklamasi seluas 157,23 Ha. Selain itu, hak dan kewajiban antara Pemprov dan Investor dari segi pembiayaan reklamasi pantai sangat tidak sepadan. Hal ini, ditentukan dalam Pasal 5, bahwa pemerintah provinsi harus memenuhi sejumlah kewajiban yang mengakibatkan biaya yang dikeluarkan mencapai 164,1 Milyar. Sementara kewajiban Investor hanya menyiapkan desain, mengurus perizinan dan menyiapkan material untuk reklamasi.

Dalam konteks payung hukum reklamasi di wilayah pesisir harus diatur dalam bentuk Peraturan Daerah Zonasi Wilayah Pesisir dan pelaksanaannya harus atas izin Menteri Kelautan dan Perikanan, sebagaimana diatur dalam Peraturan Menteri Kelautan dan Perikanan No. 17 Tahun 2013 tentang Pedoman Perizinan Reklamasi dan Peraturan Menteri PU No 40/PRT/M/2007 tentang Pedoman Perencanaan Tata Ruang Kawasan Reklamasi Pantai. ASP menilai, reklamasi CPI juga terindikasi tidak memenuhi syarat yang ditetapkan oleh UU Amdal, karena tidak pernah diumumkan permohonan dan keputusan izin lingkungan berdasarkan UU No 32 tahun 2009 tentang RPPLH.

Secara empirik dalam pelaksanaan reklamasi pantai, ternyata pihak Pemerintah Provinsi Sulawesi Selatan sama sekali tidak melibatkan DPRD Provinsi Sulawesi Selatan, atau meminta persetujuan dalam proyek reklamasi pantai tersebut. Konsekuensi mengundang reaksi dari berbagai pihak. Mengapa DPRD Provinsi tidak dilibatkan sedangkan Pemerintah Provinsi Sulawesi Selatan menggelontorkan dana sejumlah 164 Milyar dari APBD Provinsi. Pada hal dalam beberapa regulasi yang ada mengenai perizinan reklamasi pantai dan tata ruang wilayah, persetujuan atau rekomendasi dari

Vol. 20 No. 1 Mei 2018 
DPRD Provinsi merupakan suatu keharusan dalam melaksanakan reklamasi pantai.

Penolakan reklamasi ini, tidak hanya dari WALHI tetapi juga dari Koalisi Masyarakat Anti Korupsi (KMAK) Sulsel, yang dari awal mengakui telah mengendus indikasi korupsi dalam pembangunan mega proyek ini. KMAK melaporkan kasus reklamasi Pantai Losari di kawasan CPI ke KPK dengan kerugian negara yang ditimbulkan mencapai Rp 15 triliun. Dalam laporan KMAK ke KPK, Pemprov Sulsel, dalam hal ini Gubernur Sulsel Syahrul Yasin Limpo, dua pihak pengembang, yakni PT Ciputra Grup dan PT Yasmin, sebagai terlapor. Dengan realitas ini, sangat menarik untuk dikaji lebih mendalam berkenaan dengan hakikat perjanjian reklamasi pantai antara investor dengan Pemerintah Provinsi Sulawesi Selatan.

\section{B. ANALISIS DAN PEMBAHASAN}

\section{Keabsahan Perjanjian Reklamasi Pantai Antara Pemerintah Provinsi Sulawesi Selatan Dengan Investor}

\section{a. Kesepakatan}

Manusia dalam memenuhi berbagai kepentingannya melakukan berbagai macam cara, salah satu di antaranya dengan membuat perjanjian. Menurut Sudikno Mertokusumo bahwa perjanjian adalah "Hubungan hukum antara dua pihak atau lebih berdasarkan kata sepakat untuk menimbulkan akibat hukum". ${ }^{1}$ Pasal 1313 KUHPerdata menentukan bahwa "Perjanjian adalah suatu perbuatan dengan mana satu orang atau lebih mengikatkan dirinya terhadap satu orang lain atau lebih". ${ }^{2}$ Dengan demikian suatu kesepakatan berupa perjanjian atau kontrak pa- da hakikatnya adalah mengikat, bahkan sesuai dengan Pasal 1338 ayat (1) KUHPerdata, kesepakatan ini memiliki kekuatan mengikat sebagai undang- undang bagi para pihak yang membuatnya. ${ }^{3}$

Dalam perjanjian reklamasi pantai pihak Pemerintah Provinsi melakukan penawaran kepada pihak swasta, berarti dalam hal ini pihak pemerintah provinsi memberikan hak kepada pihak swasta untuk menolak atau menerima penawaran perjanjian kerjasama tersebut. Jika penawaran tersebut, diterima dan disetujui pihak swasta dan dinyatakan sebagai pemenang lelang, berati sudah ada kesepakatan dan jika penawaran tersebut ditolak, maka kesepakatan dianggap tidak pernah ada karena suatu penawaran kehilangan daya berlakunya, apabila penawaran tersebut ditolak, sudah kadaluwarsa atau penawaran tersebut ditarik kembali oleh orang atau pihak yang menawarkan.

Kontrak yang lahir dari kesepakatan (karena bertemunya penawaran dan penerimaan), pada kondisi normal adalah bersesuaian antara kehendak dan pernyataan. Namun demikian, tidak menutup kemungkinan bahwa kesepakatan dibentuk oleh adanya unsur cacat kehendak (wilsgebreke).

Kontrak yang proses pembentukannya dipengaruhi oleh adanya unsur cacat kehendak tersebut, mempunyai akibat hukum dapat dibatalkan (vernietigbaar). Dalam BW terdapat tiga hal yang dapat dijadikan alasan pembatalan kontrak berdasarkan

\footnotetext{
${ }^{1}$ Sudikno Mertokusumo, Mengenal Hukum: Suatu Pengantar, Yogyakarta: Liberty, 1999, hal. 97

${ }^{2}$ KUHPerdata (burgelijk wetboek)

${ }^{3}$ ibid
}

Vol. 20 No. 1 Mei 2018 
adanya cacat kehendak, yaitu:

\section{Kesesatan atau $d$ waling (vide Pasal 1322 BW);}

Dalam perjanjian reklamasi pantai bisa jadi terjadi kesesatan dalam perjanjian tersebut, karena pada nyatanya objek perjanjian yaitu tanah tumbuh yang menjadi lahan proyek CPI itu, ternyata milik masyarakat setempat yang ada sertifikatnya, dan telah berkekuatan hukum tetap berdasarkan putusan pada tingkat Kasasi di Mahkamah Agung. Sementara Pemerintah Provinsi berpendapat bahwa itu adalah tanah Negara, sehingga DPRD percaya dan menggelontorkan uang kurang lebih dari 300 Milyar Rupiah untuk pembangunan jalan dan wisma Negara pada lokasi tersebut.

\section{Paksaan atau dwang (Vide Pasal 1323 - 1327 BW)}

Paksaan timbul apabila seseorang tergerak untuk menutup kontrak (memberikan kesepakatan) dibawah ancaman yang bersifat melanggar hukum. Dalam perjanjian reklamasi pantai antara pemerintah provinsi dan investor dapat dipastikan tidak ada paksaan, karena melalui proses lelang yang terbuka.

\section{Penipuan atau bedrog(vide Pasal 1328 BW)}

Penipuan merupakan bentuk kesesatan yang dikualifisir, ${ }^{4}$ artinya ada penipuan bila gambaran yang keliru tentang sifat-sifat dan keadaan-keadaan (kesesatan) ditimbulkan oleh tingkah laku yang sengaja menyesatkan dari pihak lawan. Untuk berhasilnya dalil penipuan disyaratkan bahwa gambaran yang keliru itu ditimbulkan oleh rangkaian tipu daya (kunstgrepen). ${ }^{5}$

\section{b. Kecakapan}

Kecakapan (bekwaamheid- capacity) yang dimaksud dalam Pasal 1320 BW, adalah kecakapan untuk melakukan perbuatan hukum. Kecakapan untuk melakukan perbuatan hukum diartikan sebagai kemungkinan untuk melakukan perbuatan hukum secara mandiri yang mengikat diri sendiri tanpa dapat diganggu-gugat. ${ }^{6}$ Kecakapan untuk melakukan perbuatan hukum pada umumnya diukur dari standar, berikut ini :

1. Person (pribadi), diukur dari standar usia kedewasaan (meerderjarig). Pada satu sisi sebagian masyarakat masih menggunakan standar usia 21 tahun sebagai titik tolak kedewasaan seseorang dengan landasan Pasal 1330 BW jo 330 BW. Sementara pada sisi lain mengacu pada standar usia 18 tahun, sebagaimana yang di atur dalam Pasal 47 jo. Pasal 50 Undang- Undang Nomor 1 Tahun 1974 Tentang Perkawinan.

Pasal 330 BW menyatakan, bahwa Belum dewasa adalah mereka yang belum mencapai umur genap dua puluh satu tahun dan tidak kawin sebelumnya. Apabila perkawinan itu dibubarkan sebelum umur mereka genap dua puluh satu tahun, maka mereka tidak kembali berstatus belum dewasa. Mereka yang belum dewasa dan tidak

\footnotetext{
${ }^{4}$ Maksud 'dikualifisir', artinya memang terdapat kesesatan salah satu pihak, namun kesesatan ini disengaja oleh pihak lain. Jadi persamaan antara kesesatan dan penipuan adalah adanya pihak yang sesat, sedang perbedaannya terletak pada unsur kesengajaan untuk menyesatkan pada penipuan

${ }^{5}$ Niewenhuis, J. H. (1985). Pokok-Pokok Hukum Perikatan. Terjemahan Djasadin Saragih.., h. 17.

${ }^{6}$ Ibid, hal.20
}

Vol. 20 No. 1 Mei 2018 
di bawah kekuasaan orangtua, berada di bawah perwalian atas dasar dan dengan cara seperti yang diatur dalam Bagian 3,4, 5 dan 6 dalam bab ini.

Patut dipahami bahwa pengaturan standar usia dewasa dalam hubungan dengan kecakapan untuk melakukan perbuatan hukum, didasari pertimbangan perlindungan hukum bagi pihak yang tidak cakap. Karena itu, akibat kebatalan (dapat dibatalkannya) suatu kontrak karena adanya ketidakcakapan salah satu pihak, maka bobot keseimbangan bergeser ke arah pihak yang tidak cakap.

2. Rechtspersoon (badan hukum), diukur dari aspek kewenangan (bevoegheid)

Dalam hal subyek hukumnya, adalah berupa badan hukumstandar kecakapan untuk melakukan perbuatan hukum tidak menghadapi polemik seperti pada person, karena cukup dilihat pada kewenangannya (bevoeghied). Artinya kecakapan untuk melakukan perbuatan hukum didasarkan pada kewenangan yang melekat pada pihak yang mewakilinya. Dengan demikian untuk mengetahui syarat kecakapan pada badan hukum harus diukur dari aspek kewenangannya (bekwaamheid - bevoegheid).

Dapat terjadi seseorang yang cakap bertindak, akan tetapi ia tidak berwenang untuk melakukan perbuatan hukum. Sebagai contoh seorang direktur Perseroan Terbatas (PT) yang telah habis masa jabatannya sesuai dengan ketentuan anggaran dasar dan belum diangkat kembali oleh Rapat Umum Pemegang Saham (RUPS), maka tidak dapat mewakili perseroan untuk membuat dan menandatangani perjanjian (kontrak), meskipun direktur tersebut dari aspek usia telah dewasa menurut hukum.

Berdasarkan komparisi perjanjian sangat jelas bahwa dasar hukum kewenangan kedua belah pihak sangat jelas. Dari pihak Investor langsung diwakili oleh Direktur Utamanya langsung, sedangkan Gubernur Sulawesi Selatan yang mewakili pihak pemprov yang tentunya memiliki kewenangan yang sangat jelas berdasarkan Undang Undang Nomor 23 Tahun 2014 Tentang Pemerintahan Daerah, karena itu kedua belah pihak berwenang menurut hukum.

\section{c. Suatu Hal Tertentu}

Suatu hal atau obyek tertentu (een bepaald onderwerp) dalam Pasal 1320 BW, adalah prestasi yang menjadi pokok kontrak yang bersangkutan. Hal ini untuk memastikan sifat dan luasnya pernyataan-pernyataan yang menjadi kewajiban para pihak. Pernyataan-pernyataan yang tidak dapat ditentukan sifat dan luas kewajiban para pihak, adalah tidak mengikat (batal demi hukum).

Menurut Djaja S Meliala ${ }^{7}$ bahwa suatu hal tertentu maksudnya, adalah bahwa suatu hal tertentu maksudnya adalah bahwa objek perjanjian harus tertentu atau setidak-tidaknya dapat ditentukan (pasal 1333 KUHPerdata). Apabila objek tertentu tersebut dalam bentuk barang atau benda maka dapat tertuju pada barang yang sudah ada maupun barang (benda) yang baru akan ada pada kemudian hari. Dengan demikian maka yang dapat dijadikan objek perjanjian sebagai syarat suatu hal tertentu adalah bisa dalam bentuk barang/benda yang sudah ada maupun yang baru aka nada (vide Pasal 1334 KUHPerdata).

\footnotetext{
${ }^{7}$ Djaja S Meliala, Hukum Perdata dalam Perpektif BW, Nuansa Aulia, Bandung, 2014 hal. 173
} 
Sehubungan dengan perjanjian rekalamsi pantai, objek perjanjiannya adalah benda yang sudah dan benda yang baru aka nada dikemudian hari yaitu tanah tumbuh dan daerah pesisir pantai yang sudah ada sedangkan daerah yang baru akan ada dikemudian hari yaitu lahan yang telah tereklamasi yang sebelumnya berupa pantai yang belum ditimbun.

\section{d. Causa yang Diperbolehkan}

Terkait dengan pengertian " causa yang diperbolehkan' atau ada yang menerjemahkan " sebab yang halal' (eene geoorloof de oorzaak) beberapa sarjana mengajukan pemikirannya, antara lain H.F.A. Vollmar8 dan Wirjono Prodjodikoro9, yang memberikan pengertian sebab (causa) sebagai maksud atau tujuan dari perjanjian. Sedangkan Subekti10 menyatakan bahwa sebab adalah isi perjanjian itu sendiri, dengan demikian causa merupakan prestasi dan kontra prestasi yang saling dipertukarkan oleh para pihak.

Menurut Hamaker11, causa suatu kontrak adalah akibat yang sengaja ditimbulkan oleh tindakan menutup kontrak, yaitu apa yang menjadi tujuan para pihak bersama untuk menutup kontrak, dan karenanya disebut tujuan obyektif, untuk membedakannya dari tujuan subyektif (dianggap motif). Motif untuk membeli rumah adalah umumnya untuk ditempati oleh pembeli rumah tersebut, namun tidak menjadi masalah kalau motifnya akan dihadiahkan pada istri pembeli agar memberi ijin suaminya untuk kawin lagi. Dari kacamata hukum kontrak motif yang mendasari seseorang untuk menutup kontrak adalah tidak penting.

Dalam Pasal 1335 BW ditegaskan bahwa, "suatu perjanjian yang dibuat tanpa sebab atau dibuat dengan sebab yang palsu atau terlarang tidak mempunyai kekuatan." Adapun sebab yang diperbolehkan maksudnya adalah bahwa apa yang hendak dicapai para pihak dalam perjanjian atau kontrak tersebut harus disertai itikad baik dan tidak bertentangan dengan peraturan perundang- undangan, ketertiban umum, dan kesusilaan. Selanjutnya dalam 1337 BW ditegaskan bahwa,"suatu sebab adalah terlarang, apabila dilarang oleh undang-undang, atau apabila berlawanan dengan kesulilaan baik atau ketertiban umum"

Sehubungan dengan perjanjian reklamasi pantai, apabila ditelaah dengan pasal 1337 KUH Perdata maka dapat disimpulkan bahwa sebab dari perjanjian tersebut melanggar undang - undang. Segaimana diketahui bahwa objek dari perjanjian reklamasi tersebut cacat hukum karena tidak adanya rekomendasi dari menteri KKP untuk mengeluarkan izin lokasi dari proyek reklamsi tersebut. Hal i8ni dengan jelas telah melanggar Pasal 8 ayat (1) Peraturan Menteri Kelautan Dan Perikanan Republik Indonesia Nomor 28/Permen-Kp/2014 Tentang Perubahan Atas Peraturan Menteri Kelautan Dan Perikanan Nomor 17/Permen-Kp/2013 Tentang Perizinan Reklamasi Di Wilayah Pesisir Dan Pulau-Pulau Kecil, meyebutkan bahwa : "Izin Lokasi Reklamasi dengan luasan di atas 25 (dua puluh lima) hektar harus mendapatkan rekomendasi dari Menteri."

\footnotetext{
${ }^{8}$ H.FA Vollmar, Op. Cit. hal. 160.

${ }^{9}$ Wirjono Prodjodikoro, Op. Cit, hal. 35.

${ }^{10}$ Subekti Op. Cit, hal. 20.

${ }^{11}$ J. Satrio, Op. Cit hal. 312.
} 
Dari subsatansi pasal diatas mencantumkan kata "harus" berarti apabila rekomendasi tersebut diberikan berarti telah melanggar undang-undang atau dapat dikatakan izin tersebut illegal karena tidak melalui prosedur yang telah ditetapkan oleh undang-undang. Maka dapat disimpulkan bahwa syarat keempat dari syarat sahnya suatu perjanjian yaitu sebab yang halal tidak terpenuhi dari perjanjian reklamasi pantai tersebut.

Dengan memperhatikan ketentuan Pasal 1320 BW mengenai syarat sahnya kontrak, agar suatu kontrak mempunyai kekuatan mengikat (sah) maka seluruh persyaratan tersebut di atas harus dipenuhi (kesepakatan, kecakapan, hal tertentu, dan causa yang diperbolehkan). Syarat sahnya kontrak ini bersifat kumulatif, artinya seluruh persyaratan tersebut harus dipenuhi agar kontrak itu menjadi sah, dengan konsekuensi tidak dipenuhi satu atau lebih syarat dimaksud akan menyebabkan kontrak tersebut dapat diganggu gugat keberadaannya (batal/ nietig) atau dapat dibatalkan/ vernietigbaar) danbatal demi hukum.

Sehubungan dengan keempat syarat dalam Pasal 1320 BW tersebut di atas terdapat konsekuensi jika tidak dipenuhinya masing-masing syarat dimaksud. Pertama, syarat kesepakatan dan kecakapan, merupakan syarat subyektif karena berkenaan dengan diri orang atau subyek yang membuat kontrak. Kedua, syarat obyek tertentu dan causa yang diperbolehkan merupakan syarat obyektif.

Suatu kontrak yang tidak memenuhi syarat sah sebagaimana yang diatur dalam Pasal 1320 BW, baik syarat subyektif maupun syarat obyektif akan mempunyai akibatakibat, sebagai berikut: ${ }^{12}$

a. "non-eksistensi", apabila tidak ada kesepakatan maka tidak timbul kontrak.

b. vernietigbaar atau dapat dibatalkan, apabila kontrak tersebut lahir karena adanya cacat kehendak (wilsgebreke) atau karena ketidakcakapan (onbekwaamheid) - (syarat Pasal 1320 B W angka 1 dan 2), berarti hal ini terkait dengan unsur subyektif, sehingga berakibat kontrak tersebut dapat dibatalkan, dan

c. nietig atau batal demi hukum, apabila terdapat kontrak yang tidak memenuhi syarat obyek tertentu atau tidak mempunyai causa atau causanya tidak diperbolehkan (syarat Pasal 1320 BW angka 3 dan 4), berarti hal ini terkait dengan unsur objektif, sehingga berakibat kontrak tersebut batal demi hukum.

Sehubungan dengan perjanjian reklamsi pantai CPI syarat yang tidak terpenuhi adalah syarat objektif (sebabnya bertentangan dengan undang-undang) sehingga berakibat kontrak tersebut batal demi hukum.

Berdasarkan bukti melalui Surat klarifikasi Kementerian Kelautan dan Perikanan (KKP) kepada Wahana Lingkungan Hidup Indonesia (Walhi) Sulsel yang menegaskan, COI,/CPI tak punya izin lokasi dan izin pelaksanaan reklamasi.

Melihat fakta diatas bahwa memang betul belum ada rekomendasi dari Kementerian Kelautan dan Perikanan hal ini jelas bertentangan dengan Peraturan Menteri Kelautan dan Perikanan RI Nomor 17/Permen/-KP/2013 Tanggal 3 Juli 2013

\footnotetext{
${ }^{12}$ Niewenhuis, Op. Cit., h. 2
} 
Tentang Perizinan Reklamasi di Wilayah Pesisir dan Pulau-pulau Kecil pada Pasal 8 Ayat (1) menyatakan bahwa "Izin Lokasi Reklamasi dengan luasan di atas 25 hektar harus mendapat rekomendasi dari menteri". Dari subsatansi pasal diatas mencantumkan kata "harus" berarti apabila rekomendasi tersebut diberikan berarti telah melanggar undang-undang atau dapat dikatakan izin tersebut illegal karena tidak melalui prosedur yang telah ditetapkan oleh undang - undang. Maka dapat disimpulkan bahwa syarat keempat dari syarat sahnya suatu perjanjian yaitu sebab yang halal tidak terpenuhi dari perjanjian reklamasi pantai tersebut.

Kemudian oleh karena objek perjanjian tersebut bisa dikatakan bertentangan atau tidak sejalan dengan undang-undang atau peraturan yang ada maka peneliti beranggapan bahwa di dalam perjanjian reklamasi pantai antara Investor dengan Pemerintah Propinsi Sulawesi Selatan asas kebebasan berkontrak juga belum terpenuhi secara optimal dalam arti sesungguhnya atau pada hakikatnya belum sempurna. Karena apabila mengacu rumusan Pasal 1338 (1) BW yang dibingkai oleh pasal-pasal lain dalam satu kerangka sistem hukum kontrak (vide Pasal 1320,1335,1337,1338 (3) serta $1339 \mathrm{BW}$ ), maka penerapan azas kebebasan berkontrak dalam perjanjian reklamasi pantai antara Pemerintah Propinsi dan Investor harus dibingkai oleh rambu-rambu hukum lainnya. Hal ini berarti kebebasan para pihak yaitu Pemerintah Daerah Propinsi Sulawesi Selatan dan Investor dalam membuat kontrak perlu memperhatikan hal-hal sebagai berikut :

a. memenuhi syarat-syarat sahnyakontrak.

b. untuk mencapai tujuan para pihak, kontrak harus mempunyai causa,

c. tidak mengandung causa palsu atau dilarang undang- undang,

d. tidak bertentangan dengan kepatutan, kebiasaan, kesusilaan dan ketertiban umum,

e. harus dilaksanakan dengan itikadbaik.

Hubungannya dengan perjanjian reklamasi pantai antara investor dengan Pemprov.Sulawesi Selatan jelas bahwa ada kesepakatan di kedua pihak secara tertulis. Dimulai dari ikutnya PT. Yasmin dalam proses tender tentunya telah merupakan kesepakatan atas apa yang ditawarkan oleh pihak pemprof. Kemudian dari dimenangkannya PT. Yasmin pada proses lelang tersebut tentunya pihak pemprof telah sepakat atau menyetujui dari penawaran dari PT Yasmin. Kemudian diperkuat lagi dengan Mou Antara Pemerintah Provinsi Sulawesi Selatan dengan PT. Yasmin Bumi Asri dengan surat perjanjian kerjasama Nomor: 252/VII/PEMPROV/2013 dan Nomor: 231/YBA/VI1/2013 tentang Reklamasi Kawasan Center Point of Indonesia di Makassar yang ditandatangani di Makassar tanggal 29 Juli 2013. Kemudian dilakukan Perubahan Perjanjian Kerjasama mengenai masa berakhirnya perjanjian aijjara Pemerintah Provinsi Sulawesi Selatan dengan PT. Yasmin Bumi Asri dengan diterbitkannya Addendum Kesatu Perjanjian Kerjasama Nomor: 515/III/PEMPROV/2013 dan 255/YBA/II1/2015 Tentang Reklamasi Kawasan Center Point of Indonesia di Makassar yang ditandatangi di Makassar tanggal 6 Maret 2015.

Vol. 20 No. 1 Mei 2018 


\section{Reklamasi Pantai CPI Negosiasi Dalam Pembentukan Kesepakatan Para Pihak pada Perjanjian}

Kontrak pada dasarnya merupakan bagian penting dari suatu proses bisnis yang sarat dengan pertukaran kepentingan di antara para pelakunya. Oleh karena itu keberhasilan dalam bisnis antara lain juga akan ditentukan oleh struktur atau bangunan kontrak yang di buat oleh para pihak. Sebagai suatu proses, kontrak yang ideal seharusnya mampu mewadahi pertukaran kepentingan para pihak secara fair dan adil (proporsional). Oleh karena itu ada fase penting yang harus dilalui para pihak dalam proses pembentukan kontrak, yaitu negosiasi. Negosiasi dalam kontrak komersial merupakan perwujudan penerapan azas proporsionalitas menuju tahapan pembentukan kontrak.

Dalam setiap proses negosiasi kontrak sasaran atau tujuan para pihak sebenarnya hanya satu yaitu untuk mencapai kata sepakat.13Meskipun demikian, justru kesepakatan itulah yang penuh dengan misteri, sehingga melalui negosiasi tabir misteri tersebut berusaha untuk dibuka. Melalui negosiasi proses pertukaran kepentingan di antara para pihak berjalan sesuai dengan dinamika kontrak itu sendiri, artinya para pihak dihadapkan pada dua karakteristik negosiasi kontrak, yaitu sifat positif dan sifat negatif.

Menurut Budiono Kusumohamidjojo14 negosiasi bersifat "positif" atau "negatif" bukannya karena negosiasi itu bisa bersifat "baik" atau "buruk". Seharusnya tidak ada negosiasi yang bersifat baik atau buruk, suatu negosiasi akan bermuara pada "keberhasilan" atau "kegagalan". Suatu negosiasi kontrak mempunyai sifat positif, jika para pihak hendak mencapai suatu kontrak yang bersifat kerja sama. Dengan demikian, sifat positif itu diperoleh dari maksud orang untuk memulai sesuatu yang baru dan menghasilkan sesuatu yang bermanfaat. Sebaliknya, suatu negosiasi kontrak mempunyai sifat negatif jika para pihak hendak mencapai suatu perdamaian. Suatu negosiasi untuk mencapai perdamaian bersifat negatif karena melalui negosiasi itu orang hendak mengakhiri sesuatu yang negatif, yaitu perselisihan atau sengketa itu. Sifat positif atau negatif itu juga lebih disebabkan oleh suasana dialog yang berkembang di antara para pihak itu sendiri.

Menurut Anthony Klok dan Gerald S. Williams,15 kepustakaan tentang negosiasi pada umumnya menyebut negosiasi kontrak yang bersifat positif sebagai negosiasi yang kooperatif, sedangkan negosiasi kontrak yang bersifat negatif disebut negosiasi yang kompetitif. Namun demikian cara pembedaan itu tidak sepenuhnya tepat. Dalam banyak negosiasi kontrak yang bersifat positif, para pelaku negosiasi juga akan berkompetisi (bersaing) untuk memperoleh manfaat yang semaksimal mungkin dari kerja sama yang mereka bangun dalam suatu kerangka yang seadil mungkin. Sebaliknya, tidak ada negosiasi kontrak yang bersifat negatif dapat berhasil, jika para pelaku negosiasi sama sekali tidak mau bekerja sama untuk mencapai suatu kompromis. Tentunya selalu ada hal-hal yang tidak langsung disepakati, betapa pun

\footnotetext{
${ }^{13}$ Budiono Kusumohamidjojo, Panduan Negosiasi Kontrak, Grasindo, Jakarta, 1999, hal. 9

${ }^{14}$ Ibid hal 10

${ }^{15}$ Ibid., hal. 11-12.
}

Vol. 20 No. 1 Mei 2018 
men-dalamnya itikad baik dari kedua belah pihak, karenanya perlu dinegosiasikan. Sebaliknya, suatu negosiasi yang bersifat negatif juga tidak hanya diwarnai dengan perbedaan-perbedaan tajam dan prinsipiil. Suatu negosiasi yang hanya diwarnai dengan perbedaan-perbedaan tidak akan pernah menghasilkan suatu kontrak yang mengakhiri suatu perselisihan atau perbedaan dimaksud. Bahkan dalam suatu suasana dialog yang sangat tidak menguntungkan sekalipun, negosiator yang piawai akan menggunakan segala teknik yang dianggap efektif untuk mendekat-kan para pihak guna menuju suatu fokus (kesepakatan) yang sama. Hal utama yang menentukan apakah suatu negosiasi, baik yang bersifat positif maupun negatif, dapat tetap berlangsung sangat bergantung pada itikad baik para pihak. Itikad baik sebagai dasar untuk melakukan negosiasi itu harus bersifat timbal balik (resiprositas). 16

Menurut Rudhi Prasetya,17 untuk mencari kata sepakat dalam kontrak, bukan sekedar masalah bagaimana pandai "bernegosiasi". Memang kepandaian bernegosiasi merupakan salah satu faktor keberhasilan. Namun sepandai-pandainya bagaimana teknik bernegosiasi, akhirnya yang paling menentukan "bargaining position para pihak. Namun akan lebih obyektif apabila mencermati dan memperhatikan klausul- klausul dalam kontrak, apakah tidak bertentangan dengan "kepatutan" dan "keadilan" (billijkheid en redelijkheid)18, serta menguji keberadaan suatu kontrak bisnis melalui bekerjanya azas-azas pokok dalam hukum kontrak. Dengan demikian problematika mengenai perbedaan, ketidaksamaan atau ketidakseimbangan dalam berkontrak akan dapat dikaji secara lebih obyektif-porporsional, apabila diletakkan pada sendi-sendi dasar "kepatutan" dan "keadilan" (billijkheid en redelijkheid). Sebagaimana diketahui bahwa untuk sampai pada tahapan perjanjian atau kontrak, para pihak pada umumnya melakukan negosiasi agar tercapai kesepakatan. Hasil kesepakatan para pihak yang dikemas dalam bentuk kontrak merupakan hal vital dan krusial, mengingat kontrak yang disepakati ini akan mengikat para pihak dari sisi hukum. Hal yang sangat mendasar perlu dipahami bahwa segala upaya dan tahapan negosiasi yang dilalui pada akhirnya akan bermuara pada bingkai kontrak yang melahirkan keterikatan para pihak secara hukum. Pada titik ini hak dan kewajiban para pihak dirumuskan dan selanjutnya mengikat untuk dilaksanakan.

Dalam perjanjian reklamasi pantai CPI, menurut peneliti sebelum melakukan proses lelang dalam hal pengerjaan reklamsi pantai atau hubungan kontraktual dengan investor seharusnya diawali dengan proses negosiasi di antara para pihak, proses negosiasi dapat terjadi sekali saja untuk satu masalah tertentu, namun juga berulangulang (simultan) untuk masalah yang lebih rumit dan komplek seperti pada reklamsi pantai CPI . Dalam negosiasi yang positif yang dilakukan Pemerintah Propinsi Sulawesi Selatan dengan Investor memberikan manfaat yang semaksimal mungkin dan dalam kerangka yang seadil mungkin. Dengan adanya negosisi yang dilakukan dalam proyek reklamsi pantai CPI para pihak akan lebih objektif mencermati dan memperhatikan klausul-klausul dalam kontrak perjanjian reklamasi

\footnotetext{
${ }^{16}$ Ibid., hal 11-12.

${ }^{17}$ Rudhi Prasetya, "Analisa Hukum Ekonomi Terhadap Kontrak Dalam Menyongsong Era Globalisasi", Jurnal Hukum Bisnis, Volume 2,1997, hal. 21.

${ }^{18}$ Ibid hal 22.
}

Vol. 20 No. 1 Mei 2018 
tersebut apakah tidak bertentangan dengan kepatutan dan keadilan serta menguji keberadaan kontrak tersebut melalui bekerjanya azas-azas pokok dalam hukum kontrak. Dengan demikian problematika mengenai perbedaan, ketidaksamaan atau ketidakseimbangan dalam berkontrak akan dapat dikaji secara lebih obyektifporporsional, apabila diletakkan pada sendi-sendi dasar "kepatutan" dan "keadilan" (billijkheid en redelijkheid).

Menurut Garry Goodpaster negosiasi adalah proses bekerja untuk mencapai suatu perjanjian dengan pihak lain, suatu proses interaksi dan komunikasi yang sama dinamis dan variasinya, serta halus bernuansa, sebagaimana keadaan atau yang dapat dicapai orang. Donald W. Hendon dan Rebecca Angeles Hendon19menyatakan bahwa bernegosiasi adalah seni menciptakan usaha menjadi satu bentuk persuasi, dan bukannya suatu permainan kekuasaan yang kasar. Negosiasi adalah seni atau art yang mengubah sikap antipati menjadi simpati dan kemudian empati, memilih strategi yang tepat bagi setiap situasi, menciptakan potret bisnis yang benar, dan lain-lain. Donald G. Gifford20 dalam bukunya "Legal Negotiation Theory and Applications", menyatakan bahwa negosiasi merupakan suatu proses melibatkan pihak-pihak yang mencapai kata sepakat untuk saling tukar sesuatu yang diinginkan pihak lain melalui proses tawar menawar, baik mengenai hal-hal yang muncul pada situasi aktual, ketidaksepakatan maupun konflik yang potensial muncul dan berkembang. Negosiasi terjadi apabila orang lain memiliki apa yang kita inginkan dan kita bersedia menukarnya dengan apa yang diinginkan mereka.21Sebagaimana disampaikan Roger Fisher \& William Ury22 memberikan definisi negosiasi sebagai instrumen utama untuk apa yang diinginkan dari pihak lain. Negosiasi ditandai dengan komunikasi yang berkelanjutan untuk mencapai kata sepakat ketika para pihak mempunyai kepentingan yang saling dipertukarkan. Dengan demikian negosiasi mempunyai jangkauan sangat luas, dalam pelbagai aktifitas dan transaksi bisnis dengan melibatkan pihak-pihak yang berkepentingan untuk mencapai kesepakatan diantara mereka.23

UPICC juga mengakomodasi aspek negosiasi dalam pembentukan kontrak, melalui Pasal 2.12 tentang Negosiasi dengan itikad buruk (Negotiations in bad faith), menentukan bahwa:

1) Para pihak bebas untuk melakukan negosiasi dan tidak bertanggung gugat atas tidak tercapainya kesepakatan.

2) Namun demikian, salah satu pihak yang bernegosiasi atau memutuskan negosiasi dengan itikad buruk bertanggung gugat atas kerugian yang diderita pihak lain.

\footnotetext{
${ }^{19}$ Donald W. Hendon \& Rebecca Angeles Hendon, Negosiasi Berskala Global (How to Negotiate World Wide). Alih Bahasa Rosa Kristiwati, Binarupa Aksara, Jakarta1993, hal. 221

${ }^{20}$ Inns of Court School of Law-City University-London, Negotiation, Oxford University Press, London, 2004, hal 6.

${ }^{21}$ Tim Hindle, Negotiating Skills, alih bahasa P.Buntaran, Dian Rakyat, Jakarta, 2001 Op. cit., h. 5-6.

${ }^{22}$ Inns of Court School of Law-City University-London, Op Cit Hal,7

${ }^{23}$ Dennis A. Hawver, How To Improve Your Negotiaton Skills, Alexander Hamilton Institute Incorporated, New York 1982 hal. 1-2.
}

Vol. 20 No. 1 Mei 2018 
3) Itikad buruk dianggap ada, terutama bagi pihak yang memasuki atau melanjutkan negosiasi apabila bertujuan tidak untuk mencapai kesepakatan dengan pihak lain.

Pasal 2.15 tersebut sejalan dengan kebebasan berkontrak para pihak, namun dengan tegas melarang proses pembentukan kontrak melalui negosiasi yang dilandasi dengan itikad buruk. Pasal ini berupaya untuk memberikan jaminan adanya kompetisi yang sehat di antara pelaku bisnis, khususnya dalam praktik perdagangan internasional. Oleh karena itu, meskipun negosiasi masih dalam tahap pra kontraktual apabila dilakukan dengan itikad buruk, dan karenanya merugikan pihak lain maka hal ini akan menimbulkan tanggung gugat berupa ganti rugi. Pada umumnya ganti rugi yang dimaksudkan disini meliputi segala biaya yang dikeluarkan sehubungan dengan negosiasi kontrak, termasuk kehilangan kemungkinan mencapai kesepakatan kontrak lain dengan pihak ketiga disebut dengan negative interest. Sedangkan untuk ganti rugi berupa keuntungan yang akan diperoleh seandainya proses negosiasi melahirkan kontrak tidak termasuk disini disebut dengan expectation orpositive interest ${ }^{24}$.

Proses negosiasi sangat dibutuhkan dalam kontrak reklamasi pantai CPI dalam rangka terwujudnya pertukaran kepentingan yang proporsional di antara Pemerintah Sulawesi Selatan dan Investor. Negosiasi menjadi begitu penting karena berperan dalam mempertemukan kepentingan para pihak, sehingga pada akhirnya tercapai kata sepakat. Dengan demikian, bertemunya kehendak para pihak yang berkontrak maupun proporsionalitas pertukaran hak dan kewajibannya sangat ditentukan oleh proses negosiasi itu sendiri.

\section{Fungsi Azas Proporsionalitas Dalam Perjanjian Reklamasi Pantai CPI}

Menurut Niewenhuis ${ }^{25}$ latar belakang atau rasio kontrak beranjak pada tujuan terjadinya pertukaran harta kekayaan secara adil (ruilrechtvaardigheid). Pertukaran yang adil (fair exchange) akan muncul apabila dalam hubungan tersebut terwujud perikatan yang berisi prestasi dengan imbangan kontra prestasi. Menurut P.S. Atijah, ${ }^{26}$ kontrak merupakan bentuk pertukaran yang adil (fair exchange - "who contributed what") terkait dengan kewajiban kontraktualnya (exchange of obligation) yang didasarkan pada proporsi masing-masing. Kontrak merupakan bentuk pertukaran yang saling menguntungkan (ex-change benefit for benefit) ${ }^{27}$ Kewajiban kontraktual terebut tidak lain muncul karena adanya pertukaran janji diantara parapihak (exchange of promises) ${ }^{28}$ Pertukaran kepentingan (prestasi - kontra prestasi) merupakan titik tolak bagi terwujudnya keadilan bagi para pihak.

Menurut P.S. Atiyah", kontrak memiliki tiga tujuan, yaitu;

a. Pertama, kontrak wajib untuk dilaksanakan (memaksa) serta memberikan perlindungan terhadap suatu harapan yangwajar,

${ }^{24}$ Ibid hal 257

${ }^{25}$ J. H. Niewenhuis, Op. Cit, hal. 57-61. Periksa juga dalam Herlin Budiono, Op.cit, hal. 308-309.

${ }^{26}$ PS. Atijah, Op. Cit, hal. 1-8.

${ }^{27}$ P.S. Atiyah, Promises, Morals and Law, Oarendon Press, Oxford, 1981, h. 12

${ }^{28}$ David Oughton and Martin Davis, Source Book on Contract Law; $2^{\text {nd }}$ Ed., Cavendish Publishing, London, 2000, h. 21.

Vol. 20 No. 1 Mei 2018 
b. Kedua, kontrak berupaya mencegah terjadinya suatu penambahan kekayaan secara tidak adil,

c. Ketiga, kontrak bertujuan untuk mencegah terjadinya kerugian tertentu dalam hubungan kontraktual.

Agar supaya proses pertukaran dalam kontrak reklamasi pantai CPI berjalan fair para pihak dituntut untuk memahami dasar-dasar hukum kontrak. Mengapa pemahaman ini diperlukan, perlu diingat bahwa kontrak yang dibuat atau disusun oleh para pihak pada dasarnya adalah penuangan proses bisnis ke dalam rumusan bahasa hukum (kontrak). Dengan memahami dasar-dasar hukum kontrak dimaksudkan para pihak mempunyai pedoman dalam penyusunan kontrak, karena: ${ }^{29}$

a. Memberikan dasar hukum bagi kontrak yang dibuat,

b. Memberikan bingkai atau rambu-rambu aturan main dalam transaksi bisnis,

C. Sebagai batu uji atau tolok ukur eksistensi kontrak yang bersangkutan.

Dalam hubungannya dengan kegiatan reklamasi pantai, kontrak berfungsi untuk mengamankan perjanjian. Hal ini karena dalam kontrak terkandung suatu pemikiran (tujuan) akan adanya keuntungan yang diperoleh para pihak. Terkait dengan kontrak reklamasi pantai yang berorientasi keuntungan para pihak, fungsi azas proporsionalitas menunjukkan pada karakter kegunaan yang 'operasional dan implementatijf ${ }^{30}$ dengan tujuan mewujudkan apa yang dibutuhkan para pihak. Dengan demikian fungsi azas proporsionalitas, baik dalam proses pembentukan maupun pelaksanaan kontrak komersial adalah:

a. Dalam tahap pra kontrak reklamasi panati, azas proporsionalitas membuka peluang negosiasi bagi Pemerintah Propinsi Sulawesi Selatan dan Investor untuk melakukan pertukaran hak dan kewajiban secara fair. Oleh karena itu adalah tidak proporsional dan harus ditolak proses negosiasi dengan itikad buruk;

b. Dalam pembentukan kontrak, azas proporsional menjamin kesetaraan hak serta kebebasan dalam menentukan/mengatur proporsi hak dan kewajiban Pemerintah Propinsi Sulawesi Selatan dan Investor berlangsung secara fair.

c. Dalam pelaksanaan kontrak, azas proporsional menjamin terwujudnya distribusipertukaran hak dan kewajiban menurut proporsi yang disepakati/dibebankan pada para pihak;

d. Dalam hal terjadi kegagalan dalam pelaksanaan kontrak, maka harus dinilai secara proporsional apakah kegagalan tersebut bersifat fundamental (fundamental breach) sehingga menggangu pelaksanaan sebagaian besar kontrak atau sekedar hal-hal yang sederhana/kesalahan kecil (minor important). Oleh karena itu pengujian melalui azas proporsionalitas sangat menentukan dalil kegagalan pelaksanaan kontrak, agar jangan

${ }^{29}$ Loc. Cit.

${ }^{30}$ Karakter 'operasional dan impiementatifdari azas proporsionalitas hendaknya tidak diartikan bahwa azas ini dengan sendirinya berlaku mengikat para pihak - Sesuai dengan sifatnya, azas berkedudukan sebagai meta norma sehingga tidal dapat langsung mengikat para pihak. Namun yang dimaksudkan dalam kajian ini adalah seyogyanya para pihak menuangkan dan mengimplementasikan \& proporsionalitas ini ke dalam klausul- klausul kontrak yang mereka buat.

Vol. 20 No. 1 Mei 2018 
sampai terjadi penyalahgunaan oleh salah satu pihak dalam memanfaatkan klausul kegagalan pelaksanaan kontrak, semata-mata demi keuntungan salah satu pihak dengan merugikan pihak lain;

e. Bahkan dalam hal terjadi sengketa kontrak, azas proporsionalitas menekankan bahwa proporsi beban pembuktian kepada para pihak harus dibagi menurut pertimbangan yang fair.

Dengan demikian perjanjian reklamasi pantai merupakan proses mata rantai hubungan para pihak harus dibangun berdasarkan pemahaman keadilan yang dilandasi atas pengakuan hak para kontraktan. Pengakuan terhadap eksistensi hak para kontraktan tersebut termanifestasi dalam pemberian peluang dan kesempatan yang sama dalam pertukaran hak dan kewajiban secara proporsional. Tentunya fungsi azas proporsionalitas sebagai batu uji dalam pelaksanaan pertukaran hak dan kewajiban kontraktual menjadi relevan dan penting.

Dari pasal yang tertera dari perjanjian reklamasi pantai CPI dapat disimpulkan bahwa apa yang akan diperoleh pemerintah daerah berupa lahan yang telah tereklamasi sangat kecil dibandingkan apa yang diperoleh investor. Di mana pemerintah hanya mendapatkan lahan tereklamasi seluas $\pm 50,47 \mathrm{Ha}$, sedangkan pihak kedua (investor) diberikan lahan seluas \pm 106,76 Ha dari total lahan yang direklamasi seluas 157,23 Ha. Kemudian Peneliti juga berpendapat bahwa antara hak dan kewajiban antara Pemprov dan Investor dari segi pembiayaan reklamasi pantai sangat tidak sepadan. Dalam perjanjian kerjasama antara pemerintah dengan PT Yasmin Bumi Asri selaku investor disebutkan dalam Pasal 5, bahwa pemerintah provinsi harus memenuhi sejumlah kewajiban yang mengakibatkan biaya yang dikeluarkan mencapai 164,1 Milyar.

Dengan demikian, setelah menelah dan mengurai empat asas-asas kontrak yang secara teori dikenal dalam sistem hukum kontrak dan delapan asas hukum perikatan nasional serta mengaitkan dengan kenyataan yag ada dilapangan maka dapat ditarik kesimpulan bahwa perjanjian reklamasi pantai antara Pemerintah Provinsi Sulawesi Selatan dengan PT. Yasmin Bumi Asri belum memenuhi hakikat dari sebuah perjanjian reklamasi pantai yang sesungguhnya. Dalam hal perjanjian reklamasi tersebut seharusnya pihak-pihak yang menyusun draft kontrak memperhatikan asasasas hukum perjanjian agar perjanjian tersebut memiliki dasar pembenaran dan daya ikat bagi kedua belah pihak. Kemudian asas kebebasan berkontrak ini tidak boleh ditafsirkan semau-maunya membuat atau menyusun isi perjanjian, tetapi tetap harus memperhatikan asas-asas hukum yang berlaku. Ketika asas-asas hukum perjanjian tersebut diabaikan dalam suatu perjanjian atau kontrak, maka secara filosofis perjanjian atau kontrak tersebut tidak atau kurang memiliki kekuatan hukum, dan biasanya kurang memberi manfaat apalagi diharapkan untuk menciptakan kemaslahatan bagi orang banyak.

\section{PENUTUP}

Hakikat perjanjian reklamasi pantai antara Pemerintah Provinsi Sulawesi Selatan dengan investor belum terwujud sebagaimana mestinya, karena dalam perjanjian

Vol. 20 No. 1 Mei 2018 
reklamasi pantai tersebut telah mengabaikan asas-asas dalam hukum perjanjian dan syarat-syarat sahnya suatu perjanjian.

Terdapat ketidaksinkronan aturan hukum antara Pasal 8 Peraturan Menteri Kelautan Dan Perikanan Republik Indonesia Nomor 28/Permen-Kp/2014 tentang perizinan reklamasi di wilayah pesisir dan pulau-pulau kecil dengan Peraturan Presiden Nomor 122 Tahun 2012 tentang reklamasi di wilayah pesisir dan pulau-pulau kecil serta UndangUndang Nomor 23 Tahun 2014 tentang pemerintah daerah berkenaan dengan kewenangan izin lokasi reklamasi pantai. Disamping itu terdapat pula ketidaksinkronan aturan hukum antara UUPA dengan PP. No. 40 Tahun 1996 serta Undang-Undang Nomor 25 Tahun 2007 tentang penanaman modal berkenaan dengan pembaharuan hak guna usaha, hak guna bangunan dan hak pakai.

\section{DAFTAR PUSTAKA}

Ade Maman Suherman dan J. Satrio, 2010, Penjelasan Hukum Tentang Batasan Umur Kecakapan dan Kewenangan Bertindak Berdasar Batasan Umur, National Legal Reform Program, Jakarta.

Dennis A. Hawver, 1982. How To Improve Your Negotiaton Skills, Alexander Hamilton Institute Incorporated, New York.

Djaja S Meliala, 2014, Hukum Perdata dalam Perpektif BW, Nuansa Aulia, Bandung.

Fred B.G. Tumbuan,1988. "Kekuatan Mengikat Perjanjian dan Batas-Batasnya”. Makalah, Jakarta.

Muhammad Kamal, 2013. Pencegahan Kejahatan terhadap Perusakan Lingkungan (Prevention of Crimes Against Environmental Destruction) Ishlah: Jurnal Ilmiah Hukum 15 (1), 111-119

Sutan Remy Sjahdeini, 1993, Kebebasan Berkontrak dan Perlindungan yang Seimbang Bagi Para Pihak, IBI, Jakarta.

Wirjono Prodjodikoro, 1992. Azas-Azas Hukum Perdata, Sumur, Bandung.

Herry Djainal, Reklamasi Pantai dan Pengaruhnya Terhadap Lingkungan Fisik di Wilayah Pesisir Kota Ternate, Jurnal Lingkungan Sultan Agung, Volume 01, Nomor 01, April 2012.

Urip Santoso, Perolehan Hak atas tanah yang berasal dari Reklamasi Pantai, Mimbar Hukum, Volume 27, Nomor 2, Juli 2015.

Zainal Asikin, Perjanjian Kerjasama antara Pemerintah dan Swasta dalam Penyediaan Infrastruktur Publik, Mimbar Hukum, Volume 25, Nomor 1, Februari 2013.

Vol. 20 No. 1 Mei 2018 